The mediatization of religion

A theory of the media as agents of religious change

Hjarvard, Stig

Published in:

Nordic Journal of Media Studies

DOI:

10.1386/nl.6.1.9 1

Publication date:

2008

Document version

Peer reviewed version

Document license:

CC BY-NC-ND

Citation for published version (APA):

Hjarvard, S. (2008). The mediatization of religion: A theory of the media as agents of religious change. Nordic Journal of Media Studies, 6, 9-26. https://doi.org/10.1386/nl.6.1.9_1 


\title{
The mediatization of religion A theory of the media as agents of religious change
}

\author{
Stig Hjarvard \\ University of Copenhagen
}

\begin{abstract}
The article presents a theoretical framework for the understanding of how media work as agents of religious change. At the centre of this theory is the concept of mediatization. Through the process of mediatization, religion is increasingly being subsumed under the logic of the media. As conduits of communication, the media have become the primary source of religious ideas, in particular in the form of 'banal religion'. As a language the media mould religious imagination in accordance with the genres of popular culture, and as cultural environments the media have taken over many of the social functions of the institutionalized religions, providing both moral and spiritual guidance and a sense of community. Finally, the results of a national survey in Denmark are presented in order to substantiate the theoretical arguments and illustrate how the mediatization of religion has made popular media texts important sources of spiritual interest.
\end{abstract}

\section{Keywords}

Religion, popular culture, survey, mediatization, banal religion, secularization

\section{Suggested citation}

Hjarvard, Stig (2008). "The mediatization of religion. A theory of the media as agents of religious change”. Northern Lights 6(1): 9-26. doi: 10.1386/nl.6.1.9/1 


\section{Introduction}

By the help of the most sophisticated media technology, supernatural phenomena have acquired an unmatched presence in modern societies. In recent blockbuster movies like Narnia, The Lord of the Rings trilogy, and the Harry Potter film series, magicians, ghosts, elves, unicorns, monsters possessed by evil and spirits working for good are vividly alive and inhabit the world on a par with mortal human beings. The metaphysical realm is no longer something you can only imagine or occasionally see represented in symbolic forms in fresco paintings or pillars of stone. The media representations of the supernatural world have acquired richness in detail, character and narrative, making the supernatural appear natural. The salience of the supernatural world is, furthermore, supported by its mundane character in the media. Watching aliens and vampires in television series like The X Files and Buffy the Vampire Slayer week after week, season after season, and spending an hour or two every day fighting supernatural monsters in computer games, playing a magic character of your own creation, all make the world of the unreal a pretty familiar phenomenon.

The supernatural world is not confined to the media genres of fiction. Discovery Channel's television documentary series Ghosthunters (1996-) was among the first in a wave of television programmes dealing with supernatural, paranormal and traditional religious issues. In Denmark, for instance, national television has dealt with ghosts, exorcism and reincarnation in programmes like The Power of the Spirits and Travelling with the Soul, and on entertainment shows like The Sixth Sense, astrologists and chiromancers appear together with psychologists and fashion specialists. Not only has superstition, or new religion, become more prominent in the media, the institutionalized religions (Christianity, Islam and so on) have also received greater attention in factual programmes. The more highbrow channels of Danish radio (P1) and television (DR2) now frequently broadcast documentaries about religious issues and discussion programmes in which representatives of religious institutions appear. Over the last decades, the Danish press has also increased its coverage of both Christian and Islamic issues. In the period from 1985 to 2005, Rosenfeldt (2007) documents a multiplication of stories involving Christian issues (approximately three times as many) and Islamic issues (approximately eleven times as many). The publishing of the Muhammad cartoons by the daily newspaper Jyllands-Posten left no doubt that the media do indeed play a prominent role in the public circulation of religious representations and in the framing of religious controversy (Hjarvard 2006). Last but not least, the Internet has become a prominent platform for the dissemination and discussion of religious ideas, allowing many new religious movements to enter the public realm and changing the ways in which religious institutions interact with their community (Højsgaard and Warburg 2005). 
The increased presence of religious themes in the media may at first look like a negation of the ideas that secularization is the hallmark of high modernity and that the media are agents of enlightenment. Consequently, we could interpret the development as an increased tendency towards the de-secularization (Berger et al. 1999) or re-sacralization (Demerath 2003) of modern society in which secular tendencies are gradually being replaced or at least challenged by the resurgence of Christianity, Islam and newer mediatized forms of religion. However, in spite of the reappearance of religion on the media agenda, there is nevertheless a strong tendency towards the secularization of society. Norris and Inglehart (2004) have provided the most comprehensive analysis based on the available statistical data from 74 countries covering the period 1981-2001, and they report a clear correlation between the modernization of society and the decline in religious behaviour and beliefs. Thus, mediatization of religion may be considered a part of a gradual secularization: it is the historical process in which the media have taken over many of the social functions that used to be performed by religious institutions. Rituals, worship, mourning and celebration are all social activities that used to belong to institutionalized religion but have now been taken over by the media and transformed into more or less secular activities. Studying the ways religion interconnects with the media provides evidence of tendencies of secularization and of re-sacralization, and it may certainly be possible that both tendencies are at work at the same time - although in different areas and aspects of the interface between religion and media. For instance, some media genres, like news and documentaries, may in general subscribe to a secular world-view, whereas science fiction and horror genres are more inclined to evoke metaphysical or supernatural imaginations.

For a sociological understanding of the role that modern media play in religion, it is important to stress that modern media do not only present or report on religious issues; they also change the very ideas and authority of religious institutions and alter the ways in which people interact with each other when dealing with religious issues. For instance, some strands of faith were previously considered to be superstition and denounced as low culture. The increased presence of such forms of faith on international and national television has increased the legitimacy of 'superstition' and challenged the cultural prestige of the institutionalized church. As expressed by a Danish bishop after the screening of The Power of the Spirits, 'Danish culture will never be the same after this series' (Lindhardt 2004). Similarly, we have witnessed how Dan Brown's bestseller novel and movie The Da Vinci Code made new agendas for several of the institutionalized religions across the world.

It is my aim in this article to develop a theoretical framework for the understanding of how media work as agents of religious change. At the centre of this theory is the concept of mediatization: the media have developed into an independent institution in society and as a consequence, other institutions become increasingly dependent on the media and have to 
accommodate the logic of the media in order to be able to communicate with other institutions and society as a whole. Through the process of mediatization, religion is increasingly being subsumed under the logic of the media, both in terms of institutional regulation, symbolic content and individual practices. A theory of the interface between media and religion must consider the media and religion in the proper cultural and historical contexts, and the mediatization of religion is not a universal phenomenon, neither historically, culturally nor geographically. The mediatization of religion is a modern phenomenon to be found in western societies in which media have become independent institutions. Also, within western societies, there are many differences both in terms of media and religion, and the resultant theoretical framework and analytical outline may be more adequate for developments in the north-western part of Europe than in other parts of the western world. The studies conducted by Clark (2005) and Hoover (2006) clearly indicate that the evangelical movement in the United States provides an important cultural context for the interplay between media and religion. This is clearly different from a Scandinavian and Danish context with a much more limited public presence of, and low level of attendance to, the Protestant Church. Thus, the empirical findings from a Danish context that are presented at the end of this article may very well differ from the US experience. The theory must also consider the fact that media are not a unitary phenomenon. Individual media are dependent on their technological features, aesthetic conventions and institutional framework, and this can mean that the consequences for religion of the Internet and television may differ somewhat. A thorough understanding of the impact of media on religion must therefore be sensitive to the differences between media and the various ways in which they portray religion, transform religious content and symbolic forms and transfer religious activities from one institution to another.

\section{Three metaphors of media}

Joshua Meyrowitz (1993) has suggested a useful distinction between three different aspects of communication media: media as conduits, media as languages and media as environments. In his framework, these metaphors are used to categorize existing strands of research on mediated communication, but here they will specify the various ways in which religion is affected by media.

The metaphor of media as conduits draws attention to the fact that media transport symbols and messages across distances from senders to receivers. When focused on this aspect, research must deal with the content of the media: what kinds of messages are transmitted, what topics occupy the media agenda, how much attention does one theme get compared with another and so on. Following on from this position, the media are distributors of religious representations of various kinds. Most obvious perhaps are the religious key texts like the Bible, the Quran, hymn books and so on, which are also media products that are 
distributed both within religious institutions and through general media markets. However, the media in the sense of independent media production and distribution companies are only to a very limited extent channels for the distribution of texts originating from the religious institutions. Newspapers may have columns dedicated to religious announcements, and radio and television usually transmit religious services, but in most western countries this is a marginal activity. Most of the representations of religious issues in media do not originate from the institutionalized religions, but are produced and edited by the media and delivered through genres like news, documentaries, drama, comedy, entertainment and so on. Through these genres, the media provide a constant fare of religious representations that mixes institutionalized religion and other spiritual elements in new ways. The media become distributors of what I shall label banal religion and may hence serve as sources of re-enchantment.

If we consider the metaphor media as languages, our attention focuses on the various ways the media format the messages and frame the relationship between sender, content and receiver. In particular, the choices of medium and genre influence important features like the narrative construction, reality status and the mode of reception of particular messages, and, as a consequence, the media adjust and mould religious representations to the modalities of the specific medium and genre in question. A newspaper story about the papal politics towards Latin America, a horror film like The Exorcist and a computer game like World of Warcraft provide very different representations of religious issues and, indeed, involve completely different assumptions about what defines religion. In contemporary Europe and North America, the media as languages first and foremost imply that religion is formatted according to the genres of popular culture. Popular culture has always practised an often contentious representation of religious issues, but the public service obligations of radio and television, and the stricter moral control of commercial media in general, previously meant that the institutionalized religions used to have a firmer grip on the ways religion was represented in the public media. Due to the increasingly deregulated and commercialized media systems in most European countries as well as in North America, radio and television have become far more integrated into popular culture, and newer media like computer games, the Internet and so on have, from the very outset, placed the themes and narratives of popular culture at the centre of their activity. Through the language of popular culture in the media, religion has become more oriented towards entertainment and the consumer, and the approach to religion is generally more individualized.

Finally, if we consider the metaphor of media as environments, our interest concentrates upon the ways media systems and institutions facilitate and structure human interaction and communication. Due to their technical and institutional properties, public service media like the radio 
and television of the mid-twentieth century generally favoured a national, paternalistic, unidirectional (one-to-many) communication pattern, whereas the Internet of the twenty-first century favours a more global, consumer-oriented and multidirectional communication pattern. Because environments are much more stable than individual messages, this position encourages studies of wide-ranging historical changes; for instance, how the printing press stimulated the spread of scientific ideas and weakened the church's control over the individual's access to religious texts, thus supporting the individualization of belief and the rise of Protestantism (Eisenstein 1979).

In the technologically advanced societies of the twenty-first century, the media have expanded to almost all areas of society and make up pervasive networks (Castell 1996) through which most human interaction and communication must be filtered. Consequently, the media also structure feelings of community and belonging (Anderson 1991; Morley 2000). The media ritualize the small transitions of everyday life as well as the events of the larger society (Dayan and Katz 1992). In earlier societies, social institutions, like family, school and church, were the most important providers of information, tradition and moral orientation for the individual member of society. Today, these institutions have lost some of their former authority, and the media have to some extent taken over their role as providers of information and moral orientation at the same time as the latter have become society's most important storyteller about society itself.

The media's impact on religion may be manifold and at times contradictory, but as a whole the media as conduits, languages and environments are responsible for the mediatization of religion. Mediatization designates the process through which core elements of a social or cultural activity (for example, politics, teaching, religion and so on) assume media form. As a consequence, the activity is, to a greater or lesser degree, performed through interaction with a medium, and the symbolic content and the structure of the social and cultural activity are influenced by media environments and a media logic, upon which they gradually become more dependent (Hjarvard 2004, 2008; Schulz 2004).

Mediatization is not to be mistaken for the common phenomenon of mediation. Mediation refers to the communication through one or more media, through which both message and the relation between sender and receiver are influenced by the 'affordances' (Gibson 1979), that is, the enabling and constraining features of the specific media and genres involved. However, mediation in itself may not have any profound impact on social institutions like politics or religion, as long as the institutions are in control of the communication. Mediation concerns the specific circumstances of communication and interaction through a medium in a particular setting. In contrast, mediatization is about the long-term process of 
changing social institutions and modes of interactions in culture and society due to the growing importance of media in all strands of society. Mediatization is the process of social change that to some extent subsumes other social or cultural fields into the logic of the media. In the case of religion, the media - as conduits, languages and environments - facilitate changes in the amount, content and direction of religious messages in society, at the same time as they transform religious representations and challenge and replace the authority of the institutionalized religions. Through these processes, religion as a social and cultural activity has become mediatized.

\section{Banal religion}

In his book on nationalism and cultural identity, Michael Billig (1995) develops the concept of 'banal nationalism'. The study of nationalism is often focused on the explicit and institutionalized manifestations of nationalism, like nationalistic ideologies (for example, fascism) or symbols (for example, the flag). However, nationalism and national identity are not only created and maintained through the use of official and explicit symbols of the nation, but are also to a very large extent based on a series of everyday phenomena that constantly reminds the individual of his or her belonging to the nation and the national culture. Billig distinguishes between metaphorically 'waved and unwaved flags' (Billig 1995: 39); that is, between manifest and less noticeable symbols of the nation. Whereas the collective 'we' and 'them' in specific historical circumstances have evidently served to demarcate the nation against outsiders, such pronouns also live a quiet, everyday existence in other periods, providing natural, yet unnoticeable, references to the members and non-members of the national culture. It is this unnoticed, low-key usage of formerly explicit national symbols that constitutes what Billig calls 'banal nationalism'.

In continuation of Agger (2005), I take the notion of 'banal nationalism' a step further than Billig (1995) and include a whole series of everyday symbols and occurrences that only have a marginal or no prehistory as symbols of the nation or nationalism. Many cultural phenomena and symbols may be familiar symbols of aspects of both culture and society, but they are not necessarily seen as expressions of a national culture or a nationalistic ideology. In a Danish context, phenomena such as herrings and schnapps, the Roskilde rock festival, young people bathing in the North Sea and the chiming of the bells at Copenhagen's City Hall on New Year's Eve may for many people be familiar experiences that constitute parts of their cultural environment and memories. These experiences and symbols may not be related to nationalism, but can just as well be related to instances of individual history, family events or class culture. In some circumstances they may, nevertheless, be mobilized for nationalistic purposes, and acquire a whole new set of meanings. A good example of such a reinterpretation is the campaign video of the extreme right-wing party in Denmark, the Danish People's Party (Dansk Folkeparti) for the 
2001 parliamentary election. Accompanied only by music, a five-minutelong montage of still pictures of 'banal Danishness' was shown. The video conveyed a very powerful and positive picture of Denmark and Danishness, and through the usage of these banal national symbols, it systematically excluded elements of foreign culture from being worthy components of Danishness.

Just as the study of nationalism needs to take the banal elements of national culture into account, the study of religion ought to consider the fact that both individual faith and collective religious imagination are created and maintained by a series of experiences and representations that may have no, or only a limited, relationship with the institutionalized religions. In continuation of Billig (1995), I label these as banal religious representations; they consist of elements usually associated with folk religion, like trolls, vampires and black cats crossing the street; and items taken from institutionalized religion, like crosses, prayers and cowls; and representations that have no necessary religious connotations, like upturned faces, thunder and lightning; and highly emotional music.

From the point of view of human evolution (Boyer 2001; Pyssiäinen and Anttonen 2002), it seems reasonable to assume that these banal religious representations provided the first inventory of religious imaginations, and they continue to inform a kind of primary and to some extent spontaneous religious imagination. In the course of history and the subsequent differentiation of society, religion became partly institutionalized, and religious professionals produced progressively more complex and coherent religious narratives that excluded part of the banal elements as superstition and included others as part of the Holy Scripture, as well as invented new ones. Instead of accepting the institutionalized religious texts as the most valid and true sources of religion and belief and consequently considering folk religion or 'superstition' as incomplete, undeveloped or marginally religious phenomena, it is both theoretically and analytically far more illuminating to consider the banal religious elements as constitutive for religious imagination, and the institutionalized religious texts and symbols as secondary features, in a sense as rationalization after the fact.

The label 'banal' does not imply that these representations are less important or irrelevant. On the contrary, they are primary and fundamental in the production of religious thoughts and feelings, and they are also banal in the sense that their religious meanings may travel unnoticed and can be evoked independently of larger religious texts or institutions. The religious meaning of banal religious elements rests on basic cognitive skills that help ascribe anthropomorphic or animistic agency to supernatural powers, usually by the means of counterintuitive categories that arrest attention, support memory and evoke emotions. Thus, banal religious elements are about the supernatural and intentional force behind a sudden strike of lightning (ascribing agency), or about dead people who still walk about in 
the night (counterintuitive mix of categories). The holy texts, iconography and liturgy of institutionalized religions may contribute to the stockpile of banal religious elements, and as such they may circulate and activate meanings that are more or less related to the authorized religious interpretation. The power relationship between banal religious representations and institutionalized religion may, of course, vary historically and geographically, but the increasing role of media in society seems to make room for more of the banal religious representations.

\section{Enchanting media}

According to Max Weber (1998 [1904]), the modern world is characterized by the steady advance of rationality. As social institutions became more and more differentiated and specialized, the bureaucracy, the military, the industry and so on were subsumed into the logic of rationality. Consequently, the modern world was disenchanted: as magical imagination, religion and emotions - in short, irrationality - lost ground to the allencompassing logic of modern institutions, modern man gradually became imprisoned in an 'iron cage' of rationality. Although Weber's analysis of the role of rationality in modern society may still apply, his diagnosis of a progressive disenchantment is hardly valid. In the muddy reality of modern culture, rationality thrives next to irrationality. As the two authoritarian catastrophes of the twentieth century, fascism and Stalinism, bear witness to, extreme rationalism may very well go hand in hand with rabid irrationalism like the cultic celebration of a leader, mythological stories and prophecies, and diabolical depictions of the enemies.

Irrationalism may also, in normal social conditions, be rationalism's bedfellow. As Campbell (1987) demonstrates in his analysis of the interconnections between the spread of consumer culture and the rise of a romantic sensibility, the advance of rationality is only one side of the story. Ritzer (1999) has developed Campbell's argument in an analysis of the postmodern consumer culture, in which 'cathedrals of consumption' like shopping malls, theme parks and so on stage consumption in spectacular settings in order to endow the goods of mass production with extraordinary qualities and provide a magical experience. At the same time that both the production and distribution of consumer goods are subjected to still higher levels of 'McDonaldization', that is, more calculation, effectiveness and technological control, the goods themselves and the process of consumption are bestowed with magical meanings in order to re-enchant a still more soulless world of identical consumer goods.

In a similar vein, religions may provide a source of re-enchantment in the modern world. In continuation of Gilhus and Mikaelson (1998), I argue that the advance of new religious movements indicates the return of 'enchanting' elements from a premodern world, while at the same time these new religions are a source for identity and meaningfulness for modern self-reflexive individuals who, increasingly, are left alone with the 
responsibility of constructing a purpose in life. At the same time that secularization relegated institutionalized religion to the periphery of society, less organized and more individualized forms of religions seemed to emerge within various institutions, including businesses and industries where quasi-religious elements inform management training, branding and so on. It should be noted, however, that neither the old nor the newer kinds of religion necessarily imply a re-enchantment of the modern world. The intellectualization of modern Protestantism and the tight behavioural control within certain Islamic fundamentalist groups are two very different examples of religious developments that diminish the enchanting potential of religion.

In the same way that the new religious movements have done, the media contribute to a re-enchantment of the modern world (Murdock 1997; Martin-Barbero 1997). The media are large-scale suppliers of narratives fictional as well as factual - about adventures, magical occurrences, the fight between good and evil and so on (Clark 2005). The media are, of course, also a source of information, knowledge and enlightenment and as such propagators of reason, but at the same time they are a well of fantasies and emotional experiences. The media have become society's main purveyor of enchanted experiences. When Ritzer (1999) singles out the 'cathedrals of consumption' as the re-enchanting institutions par excellence in modern society, he is in fact only pointing towards some specific media industries. A theme park like Disneyland magnificently re-enacts narratives from a single media mogul, and the shopping mall's attempt to induce consumption with extraordinary experiences usually relies on the workings of advertising techniques, licensing of media brands, and physical environments saturated by pop music and television screens. In a similar vein, I argue that a series of new religious movements has achieved a greater resonance among its audience because the media have published similar stories. For instance, there are strong interdependencies between the media's continuous preoccupation with aliens in general and the Roswell mythology in particular, and the proliferation of quasi-religious beliefs in aliens (Rothstein 2000; Lewis 2003).

It may be said that religious messages have always been distributed through the media: the book has been an instrument of teaching and a source of key holy texts, and the church may, from a certain perspective, also be considered a communication medium with a whole series of genres like the sermon, psalms and so on. However, the both quantitative and qualitative development that the media have undergone in society is overlooked in this argument. In the past, the mass media were very much in the service of other social institutions. Books and journals were in the service of religious institutions, the scientific institution and the cultural public sphere, and newspapers were very much the instruments of political parties and movements. In a North European context, radio and television were cultural institutions and, through an elaborate scheme of political and cultural control, broadcast a balanced representation of political as 
well as cultural institutions in society.

Moving towards the end of the twentieth century, most media gradually lost their close relationship with specific social institutions, organizations and parties, and the media themselves became independent institutions in society. Consequently, the media no longer see themselves as purveyors of other institutions' agendas; instead, their activities are much more attuned to the service of audiences - very often incorporating the logic of a commercial market. Phrased differently, the media increasingly organize public and private communication in ways that are adjusted to the individual medium's logic and market considerations. Other institutions are still represented in the media, but their function becomes progressively more that of providers of raw material, which the media then use and transform for the purpose of the media themselves. The liturgy and iconography of the institutionalized religions become a stockpile of props for the staging of media narratives. For example, popular action adventure stories about Indiana Jones in Raiders of the Lost Ark, Lara Croft in Tomb Raider, and Van Helsing blend and recontextualize all sorts of religious, pagan and secular symbols in new and unexpected ways. In sum, the media as cultural institutions become prominent producers of various religious imaginations, rather than conveyors of the messages of religious institutions.

\section{Community and rituals}

Considering the media as environments, we may take the etymology of the words 'medium' and 'communication' as a starting point. The word 'medium' originates from the Latin medius, meaning 'in the middle', and the word 'communication' derives from the Latin communicare, meaning 'to share or to make common'. Thus, the media are located at the centre of or between people, and through the media, people share experiences that become common knowledge. A considerable part of media studies is concerned with these communal aspects of media and communication. James Carey (1989) argued that besides transporting information, the significance of the media lies in their cultural functions, that is, in their ability to create and sustain communities and to regulate the relationship and belonging between an individual and the society as a whole.

As Dayan and Katz (1992) have demonstrated in empirical studies, the media carry out collective rituals with a highly social integrative function. Broadcasting media have performed a vital role in the ritualization of important societal transitions, like the funeral of presidents, celebration of national feasts, inauguration of a new king and so on. Radio and television's live broadcasts of such events make it possible for a whole community (region, nation or world) both to witness and participate in the ceremony. Such media events deepen the emotional ties between community and members and make the events part of the community's collective memory. The media also become important for the collective mourning and coping with grief in cases of tragic events, like the terror attack in the United 
States on 11 September 2001. Kitch (2003) has shown how the news magazines, Time and Newsweek, in their coverage of the events did not only provide information, but also a kind of psychological help by guiding readers through consecutive stages of grief and providing resilience and closure to a national catastrophe. The treatment of collective feelings is not reserved for the big catastrophes; it is a recurrent feature of the media, and they may not only be responsible for emotional guidance, they may also facilitate the construction of collective emotions in the first place. A celebrity event like the death of Princess Diana was made into an international event by the media, and the media both built up emotional responses and provided examples of how to express sorrow in a number of ways, for example, by laying flowers at embassies, lighting candles and so on.

During ritual events, an interesting interplay between the media and the church can often be noticed. Whether it is a tragic disaster like the Asian tsunami (26 December 2004) or a national celebration, like the wedding of the Danish Crown Prince Frederik to Mary Donaldson (14 May 2004), the transmission of a religious ceremony plays a minor, yet important role. The majority of the media coverage of such events is carried out by the media themselves using their traditional genres and formats like news, interviews, documentary, live commentary and so on.

However, ceremonial actions are best performed as direct transmissions; for a moment the media pass the baton to another social institution, making it temporarily responsible for the performance of the ritual. In other words, when the media try to be at their most solemn, they perform as nakedly as possible: they stage themselves as pure channels of transmission, connecting the community to the religious institution that is conducting the memorial service or performing the wedding ritual. As Cottle (2006) has argued, media rituals are not necessarily consensual or affirmative of a dominant social order. They may occasionally be 'politically disruptive or even transformative in their reverberations within civil and wider society' (Cottle 2006: 411). This may also apply to media rituals concerned with religious issues. Thus, the media have not only taken over the performance of affirmative rituals that were previously performed by the church, but media rituals may also serve to transform religious imagination and its social status. For instance, the global media events related to the film premiere of The Lord of the Rings trilogy may have been crucial to the increase in cultural prestige of the fantasy genre in general, at the expense of institutionalized religious imagination.

Rothenbuhler (1998) has pointed towards both the habitual and ritual aspects of the use of the media itself. For most people, the use of media is embedded in everyday routines, and the use of specific media and genres also serve to mark minor and major transitions in the course of the day, the week, the year and so on. The sound of the morning radio and reading the newspaper indicate the beginning of the day in the same way that the late evening news on television ritualizes the end of the day. Previously, religious institutions provided such temporal orientation by ringing the 
church bells, conducting morning and evening prayers and so on. Today, the media mark such nodal points in the temporal flow of everyday life.

A key activity of religious institutions is the worship of symbols, gods and saints, but they no longer enjoy a monopoly in this field. The media frequently promote worship behaviour. A whole section of weekly magazines makes a living out of facilitating para-social relationships (Horton and Wohl 1956) between the audience of ordinary people and the celebrity world of media personalities, movie stars, royal families, the rich and the famous and so on. The film, television and music industries are consciously trying to develop cult phenomena, fan clubs and idolization as an integral part of the marketing efforts, but worship-like behaviour may also emerge spontaneously. In a similar vein, modern corporate branding strategies try to create both a cultural and spiritual relationship between brand, employees and consumers.

Jenkins (1992) specified the characteristics of media fan cultures. Among other features, the fans develop a special mode of reception of the key texts, and the fans constitute a kind of interpretative community as well as an alternative social grouping. Furthermore, fan cultures often take part in the development of an 'art world', that is, special artefacts that in various ways comment on and pay tribute to the worshipped media products. Fan cultures share many of the characteristics of religious groups, although they in substance - what the adoration is directed towards - may differ. The fans do not necessarily believe that the media's heroes and idols possess divine powers, but, on the other hand, fans do often treat media idols as if they were saints. As Hills (2002) argued, the similarities do not necessarily lead us to equate fan cultures with religious communities. Instead, the parallels bear witness to the fact that a series of religious activities, like worship and idolatry, can without major changes be recontextualized in more or less secular settings.

\section{Surveying the media's spiritual function}

In order to empirically validate the above-mentioned arguments about the interrelationship between media and religion, a series of questions were posed in consecutive surveys among a representative sample of the Danish adult population (18 years or older) during 2005. The first question aimed to chart to what extent Danes use the media as sources to engage in spiritual issues. The questions invited answers that implied a very broad understanding of religion, including 'banal religion'. As the results in Table 1 indicate, discussion with family members and close friends was the most frequent way to engage in spiritual issues. Next, the use of television programmes, non-fiction books and the Internet were frequent ways of engaging in spiritual topics. It is interesting that the institutionalized ways of engaging in spiritual issues - going to church or reading religious texts - were rather marginal activities compared with the use of media. Reading the Bible (or 
other religious texts) was the least frequent way mentioned among the possible answers. Reading a novel was just as frequently a way to engage in spiritual issues as going to church. That discussion with family and close friends plays such a prominent role (rather than talking to the minister or other members of a religious congregation) may reflect the fact that spiritual issues in a highly modernized society are considered private and personal, rather than public and social, while at the same time, family and friendship have come to serve very emotional functions (Giddens 1992). It should also be noted that many people have not engaged in such matters at all: more than 40 per cent have neither used the media nor other possibilities of exploring spiritual issues.

The next question illuminated the extent to which specific media and genres were used as sources of the fight between good and evil. As such, the question related to the media as sources of moral orientation, not necessarily of spiritual guidance, although these aspects may be intertwined.

Not surprisingly, as Table 2 demonstrates, narrative and fictional media and genres provide most stories that have made a profound impression on the respondents. But factual news is also a frequent source of stories about the fight between good and evil and, accordingly, the two Danish TV newscasts, $T v$-Avisen and Nyhederne, are frequently mentioned as television programmes that have provided such stories. Religious texts have, to a very limited extent, made a profound impression on the Danes in this respect. The question invited the respondents to list concrete titles of media products, and the most frequent was the Lord of the Rings film trilogy. 


\begin{tabular}{|l|c|}
\hline \multicolumn{1}{|c|}{ Ways of engaging in spiritual issues } & Per cent \\
\hline Discuss with family and close friends & 30.7 \\
\hline Watch television programmes & 25.7 \\
\hline $\begin{array}{l}\text { Read non-fiction books (e.g. philosophy and } \\
\text { psychology) }\end{array}$ & 14.9 \\
\hline Visit websites/Internet discussions & 11.5 \\
\hline Read novels & 10.5 \\
\hline Attend church ceremonies & 10.5 \\
\hline Listen to radio & 9.2 \\
\hline Attend meetings/public lectures & 8.9 \\
\hline Go to cinema & 7.3 \\
\hline Read the Bible (or other holy scripture) & 5.2 \\
\hline Other & 4.6 \\
\hline Did not engage in such issues & 42.8 \\
\hline
\end{tabular}

Table 1: Ways of engaging in spiritual issues

Question: 'People may have an interest in spiritual issues, including faith, folk religion, ethics, magical experiences, life and death and so on. If you are interested in such issues, how did you engage in them during the last couple of months?'

Note: The respondents were asked to tick a maximum of three possibilities, thus, the sum exceeds 100 per cent. The question was part of the survey undertaken by the Zapera research institute's quarterly Internet-based survey in Denmark in 2005. $\mathrm{N}=1005$. 


\begin{tabular}{|l|c|}
\hline & Per cent \\
\hline Film & 41.1 \\
\hline Television programme & 25.2 \\
\hline Fiction novel & 22.0 \\
\hline Newspaper & 14.4 \\
\hline Computer game & 11.4 \\
\hline Internet & 6.7 \\
\hline Magazine monthly/weekly & 6.0 \\
\hline Radio programme & 6.0 \\
\hline Religious books or texts & 5.5 \\
\hline Other & 3.6 \\
\hline Cannot remember any/don't know & 41.4 \\
\hline
\end{tabular}

Table 2: Media stories about the fight between good and evil

Question: 'The media are full of stories about the fight between good and evil. It may be feature films (e.g. Star Wars), novels (e.g. Harry Potter), religious books (e.g. the Bible), factual programmes (e.g. television news) and so on. Please tick 1-3 media in which you have experienced a story about the fight between good and evil that has made a profound impression on you. If you remember the title, you may specify.'

Note: The respondents were asked to tick a maximum of three possibilities, thus, the sum exceeds 100 per cent. The question was part of the survey undertaken by the Zapera research institute's quarterly Internet-based survey in Denmark in 2005. $\mathrm{N}=1005$.

Among the most frequently mentioned films were the Harry Potter movies, the Danish Adams AEbler, the German Der Untergang and the American Passion of the Christ and Constantine. Among fictional novels, Dan Brown's The Da Vinci Code and Angels \& Demons are frequently mentioned together with (again) the Harry Potter books and the book The Lord of the Rings, as well as the Danish fantasy series The Shamer Chronicles. Among the explicit religious writings, the Bible is frequently mentioned. In order to examine whether media not only support an existing interest in spiritual issues but also encourage a further interest in such matters, four popular media products were singled out because of their explicit, yet somewhat different, ways of thematizing these issues. The respondents were asked if these media products increased their interest in 'magic and fantasy', 'spiritual issues' and/or 'religious issues' respectively. This differentiation of possible answers was made in order to distinguish between various aspects of religious issues, since one way of addressing an interest in religion may render other important aspects invisible. 'Magic and fantasy' may be said to highlight the supernatural and folk religious aspects; 
'spiritual issues' may connote existential, philosophical and/or emotional aspects; and 'religious issues' may designate an interest in the institutionalized and formal features of religion.

As Table 3 shows, the Harry Potter stories, Dan Brown's novels and the Lord of the Rings trilogy have all increased interest in 'magic and fantasy' for about a third of the respondents. The computer game World of Warcraft increased the respondents' interest in 'magic and fantasy' in 22.5 per cent of the cases. It should also be noted that most people did not report an increased interest in such aspects in all of the four cases. When it comes to the media product's effect on the interest in 'spiritual issues' (Table 4), they are lower in the case of the Harry Potter stories, the Lord of the Rings trilogy and the computer game World of Warcraft. However, more than one out of ten respondents stated that these media products increased his or her interest in spiritual issues. With regards to an increased interest in 'religious issues' (Table 5), there was a further drop in percentages for these three media products; however, there were still some respondents who felt that, for instance, Harry Potter made a difference in this topic. Dan Brown's novels display a rather different pattern compared to the others. His books are more prone to encourage an interest in the spiritual and, even more so, in the institutionalized bearings of religion than any of the other three media products.

More than half of the respondents reported an increased interest in religious issues after reading those novels. This is not surprising, since Dan Brown's novels explicitly deal with the spiritual and institutionalized aspects of Christianity. It is perhaps much more surprising that media narratives, which at first glance seem to have only a remote, if any, relationship to religion, like for instance Harry Potter (Sky 2006), nevertheless stimulate an interest in supernatural and spiritual issues, and even - although to a limited extent encourage interest in institutionalized religion. An increased interest in such matters does not necessarily equate an increased belief in magic or religion; on the contrary, it may - as the case of Dan Brown's books demonstrates - go hand in hand with a sceptical awareness and critique of dominant forms of religion. The results of the surveys demonstrate, however, that the media have acquired a prominent role in the realm of religion, and people's interest in such matters is prompted by the media institution. 


\begin{tabular}{|l|c|c|c|c|}
\hline $\begin{array}{c}\text { The media } \\
\text { story has } \\
\text { increased } \\
\text { my interest } \\
\text { in magic and } \\
\text { fantasy }\end{array}$ & $\begin{array}{c}\text { Harry Potter } \\
\text { stories } \\
\text { (novels, films } \\
\text { and/or } \\
\text { computer } \\
\text { games) }\end{array}$ & $\begin{array}{c}\text { Dan Brown's } \\
\text { novels (Da } \\
\text { Vinci Code } \\
\text { and/or } \\
\text { Angels \& } \\
\text { Demons) }\end{array}$ & $\begin{array}{c}\text { Lord of the } \\
\text { Rings trilogy } \\
\text { (novel, films } \\
\text { and/or } \\
\text { computer } \\
\text { game) }\end{array}$ & $\begin{array}{c}\text { World of } \\
\text { Warcraft } \\
\text { (computer } \\
\text { game) }\end{array}$ \\
\hline Yes & 32.3 & 29.3 & 35.2 & 22.5 \\
\hline No & 64.6 & 68.3 & 62.6 & 75.5 \\
\hline Don't know & 3.1 & 2.4 & 2.1 & 2.0 \\
\hline
\end{tabular}

Table 3: The effect of different media stories on the interest in magic and fantasy

\begin{tabular}{|l|c|c|c|c|}
\hline $\begin{array}{c}\text { The media } \\
\text { story has } \\
\text { increased } \\
\text { my interest } \\
\text { in spiritual } \\
\text { issues }\end{array}$ & $\begin{array}{c}\text { Harry Potter } \\
\text { stories } \\
\text { (novels, films } \\
\text { and/or } \\
\text { computer } \\
\text { games) }\end{array}$ & $\begin{array}{c}\text { Dan } \\
\text { Brown's } \\
\text { novels } \text { (Da } \\
\text { Vinci Code } \\
\text { and/or } \\
\text { Angels \& } \\
\text { Demons) }\end{array}$ & $\begin{array}{c}\text { Lord of the } \\
\text { Rings } \\
\text { (novel, films } \\
\text { and/or } \\
\text { computer } \\
\text { game) }\end{array}$ & $\begin{array}{c}\text { World of } \\
\text { Warcraft } \\
\text { (computer } \\
\text { game) }\end{array}$ \\
\hline Yes & 11.5 & 38.4 & 13.4 & 12.1 \\
\hline No & 84.5 & 58.1 & 83.7 & 86.5 \\
\hline Don't know & 4.1 & 3.5 & 2.9 & 1.4 \\
\hline
\end{tabular}

Table 4: The effect of different media stories on the interest in spiritual issues

\begin{tabular}{|l|c|c|c|c|}
\hline $\begin{array}{c}\text { The media } \\
\text { story has } \\
\text { increased } \\
\text { my interest } \\
\text { in religious } \\
\text { issues }\end{array}$ & $\begin{array}{c}\text { Harry Potter } \\
\text { stories } \\
\text { (novels, films } \\
\text { and/or } \\
\text { computer } \\
\text { games) }\end{array}$ & $\begin{array}{c}\text { Dan } \\
\text { Brown's } \\
\text { novels } \text { (Da } \\
\text { Vinci Code } \\
\text { and/or } \\
\text { Angels \& } \\
\text { Demons) }\end{array}$ & $\begin{array}{c}\text { Lord of the } \\
\text { Rings } \\
\text { (novel, films } \\
\text { and/or } \\
\text { computer } \\
\text { game) }\end{array}$ & $\begin{array}{c}\text { World of } \\
\text { Warcraft } \\
\text { (computer } \\
\text { game) }\end{array}$ \\
\hline Yes & 4.5 & 53.5 & 7.2 & 7.1 \\
\hline No & 91.7 & 43.1 & 90.1 & 90.0 \\
\hline Don't know & 3.7 & 3.4 & 2.7 & 2.8 \\
\hline
\end{tabular}

Table 5: The effect of certain media stories on the interest in religious issues

Note: Tables 3, 4 and 5 indicate the effect of certain media stories on the interest in magic and fantasy, spiritual issues and religion; in percentage (vertical) of respondents having read, seen or played at least one version of the media story in question. Among the total number of respondents $(\mathrm{N}=1007) 588 \mathrm{had}$ read, seen or played at least one Harry Potter story; 350 had read at least one of the two novels by Dan Brown; 716 had read, seen or played Lord of the Rings, and 133 had played the computer game World of Warcraft. The questions were part of the quarterly Internetbased survey undertaken in Denmark in 2005 by the Zapera research institute. 


\section{Epilogue}

In this article, a framework has been developed to conceptualize the ways that media may change religion. The developments are complex and do not necessarily have a uniform impact on religion; in some instances, media may further a re-sacralization of society, in others, they undermine the authority of institutionalized religion and promote secular imaginations, rituals and modes of worship. At a general level, these processes share a common feature: they are all evidence of the mediatization of religion. Through mediatization, religious imaginations and practices become increasingly dependent upon the media. As conduits of communication, the media have become the primary source of imagery and texts about magic, spiritualism and religion, and as languages the media mould religious imagination in accordance with the genres of popular culture. The media as cultural environments have taken over many of the social functions of the institutionalized religions, providing both moral and spiritual guidance and a sense of community. Consequently, institutionalized religion in modern, western societies plays a less prominent role in the communication of religious beliefs and, instead, the banal religious elements of the media move to the fore of society's religious imagination.

\section{References}

Agger, G. (2005), Dansk tv-drama (Danish Television Drama), Frederiksberg: Samfundslitteratur.

Anderson, B. (1991), Imagined Communities: Reflections on the Origin and Spread of Nationalism, London: Verso.

Berger, P., Sacks, J., Martin, D., Weiming, T., Weigel, G., Davie, G. and An-Naim, A. (eds) (1999), The Desecularization of the World: Resurgent Religion and World Politics, Washington DC: Ethics and Public Policy Center.

Billig, M. (1995), Banal Nationalism, London: Sage.

Boyer, P. (2001), Religion Explained: The Human Instincts that Fashion Gods, Spirits and Ancestors, London: William Heinemann.

Campbell, C. (1987), The Romantic Ethic and the Spirit of Modern Consumerism, Oxford: Basil Blackwell.

Carey, J. (1989), Communication as Culture: Essays on Media and Society, Winchester, MA: Unwin Hyman.

Castell, M. (1996), The Information Age: Economy, Society and Culture, vol. 1-3, Oxford: Blackwell.

Clark, L.S. (2005), From Angels to Aliens: Teenagers, the Media, and the Supernatural, Oxford: Oxford University Press.

Cottle, S. (2006), 'Mediatized Rituals: Beyond Manufacturing Consent', Media, Culture \& Society, 28: 3, pp. 411-32.

Dansk Folkeparti (2001), Valgkampsvideo (Danish People’s Party: Election Campaign Video). http://www.danskfolkeparti.dk/Valgfilm.asp. Accessed May 5th, 2008. Dayan, D. and Katz, E. (1992), Media Events: The Live Broadcasting of History, Cambridge, MA: Harvard University Press.

Demerath III, N.J. (2003), 'Secularization Extended: From Religious “Myth” to Cultural 
Commonplace', in R.K. Fenn (ed.), Sociology of Religion, Oxford: Blackwell.

Eisenstein, E.L. (1979), The Printing Press as an Agent of Social Change, Cambridge:

Cambridge University Press.

Gibson, J.J. (1979), The Ecological Approach to Visual Perception, Boston: Houghton

Mifflin.

Giddens, A. (1992), The Transformation of Intimacy: Sexuality, Love, and Eroticism in Modern Societies, Palo Alto: Stanford University Press.

Gilhus, I.S. and Mikaelsson, L. (1998), Kulturens refortrylling: Nyreligiøsitet i moderne samfunn (The Re-enchantment of Culture: New Religions in Modern Societies), Oslo: Universitetsforlaget.

Hills, M. (2002), Fan Cultures, London: Routledge.

Hjarvard, S. (2004), 'From Bricks to Bytes: The Mediatization of a Global Toy Industry', in I. Bondebjerg and P. Golding (eds), European Culture and the Media, Bristol: Intellect Books, pp. 43-63.

(2006), 'Religion og politik i mediernes offentlighed' ('Religion and Politics

in the Public Sphere of the Media'), in L. Christoffersen (ed.), Gudebilleder:

Ytringsfrihed og religion i en globaliseret verden (Images of the Gods: Freedom of Speech and Religion in a Globalized World), Copenhagen: Tiderne Skifter, pp. 44-71.

(2008), 'The Mediatization of Society', Nordicom Review, 2, (in press).

Hoover, S.M. (2006), Religion in the Media Age, London: Routledge.

Horton, D. and Wohl, R. (1956), 'Mass Communication and Para-Social Interaction:

Observation on Intimacy at a Distance’, Psychiatry, 19, pp. 215-29.

Højsgaard, M.T. and Warburg, M. (eds) (2005), Religion and Cyberspace, London:

Routledge.

Jenkins, H. (1992), “'Strangers No More, We Sing”: Filking and the Social Construction of the Science Fiction Fan Community', in L. Lewis (ed.), The Adoring Audience:

Fan Culture and Popular Media, London: Routledge, pp. 208-37.

Kitch, C. (2003), 'Mourning in America: Ritual, Redemption, and Recovery in News

Narrative after September 11', Journalism Studies, 4: 2, pp. 213-24.

Lewis, J. (ed.) (2003), The Encyclopaedic Sourcebook of UFO Religion, New York:

Prometheus Books.

Lindhardt, J. (2004), 'Overtro er det glade vrøvl’ ('Superstition is Sheer Nonsense’),

Dagbladet Politiken, 3 January.

Martin-Barbero, J. (1997) 'Mass Media as a Site of Resacralization of Contemporary

Culture', in S. Hoover \& K. Lundby (eds.), Rethinking Media, Religion and

Culture, Thousand Oaks, Calif.: Sage, pp. 102-116.

Meyrowitz, J. (1993), 'Images of Media: Hidden Ferment - and Harmony - in the

Field', Journal of Communication, 43: 3 (Summer), pp. 55-66.

Morley, D. (2000), Home Territories: Media, Mobility, and Identity, London: Routledge.

Murdock, G. (1997), 'The Re-Enchantment of the World: Religion and the Transformations of Modernity', in S.M. Hoover and K. Lundby (eds), Rethinking

Media, Religion and Culture, London: Sage, pp. 85-101.

Norris, P. and Inglehart, R. (2004), Sacred and Secular: Religion and Politics Worldwide, Cambridge: Cambridge University Press.

Pyssiäinen, I. and Anttonen, V. (eds) (2002), Current Approaches in the Cognitive Science of Religion, London: Continuum.

Ritzer, G. (1999), Enchanting a Disenchanted World: Revolutionizing the Means of 
Consumption. Thousand Oaks, Calif.: Pine Forge Press.

Rosenfeldt, M.P. (2007), 'Hvor meget fylder religion?' ('How Much Space does Religion Take Up?'), Kritisk Forum for Praktisk Teologi, 109 (October), Copenhagen: Anis, pp. 31-47.

Rothenbuhler, E. (1998), Ritual Communication: From Everyday Conversation to Mediated Ceremony, London: Sage.

Rothstein, M. (2000), UFOer og rumvcesener: Myten om de flyvende tallerkener (UFOs and Aliens: The Myth of the Flying Saucers), Copenhagen: Gyldendal.

Schulz, W. (2004), 'Reconsidering Mediatization as an Analytical Concept', European Journal of Communication, 19: 1, pp. 87-101.

Sky, J. (2006), 'Harry Potter and Religious Mediatization', in J. Sumiala-Seppänen, K. Lundby and R. Salokangas (eds), Implications of the Sacred in (Post)Modern Media, Gothenburg: Nordicom, pp. 235-54.

Weber, M. (1998 [1904]), The Protestant Ethic and the Spirit of Capitalism, Los Angeles: Roxbury. 